Theological Research • volume 2 (2OI4) number I • P. $67-84$ DoI: http://dx.doi.org/Io.15633/thr.679

SZYMON DRZYŻDŻYK

ZuZanna KosińsKa

The Pontifical University of John Paul II in Krakow, Poland

\title{
Immutability of God in Christian Terms
}

\begin{abstract}
This article deals with the issue of the immutability of God in Himself. What is meant by "immutability" and why God should (or must) be immutable? Doesn't $\mathrm{He}$ - whom Christians preach - contradict His immutability by showing interest in man? These questions, taken by a number of philosophers and theologians have appeared more or less frequently throughout history. The article is devoted to the immutability of God as one and the Holy Trinity on the grounds of Christianity. The article quotes the thoughts of representatives from the Church in the West and in the East - Tertullian and Origen. This thought formed in an era when Trinitarian heresy flourished and had a significant impact on the further development of theological reflection. Then the theological and philosophical position of Thomas Aquinas is taken into account as one who in his investigations on the nature of God used the components of ancient Greek philosophy.
\end{abstract}

\section{KeYWORDS}

God, immutability, suffer, St Thomas Aquinas. 


\section{INTRODUCTION}

The truth about the immutability of God has been the subject of debate among philosophers and theologians from different religious and philosophical environments and systems. Adopted by Christianity, it has become one of the attributes of God's nature and an indispensable element of statements concerning His existence and activities. Christian theology, which has been developing for many centuries, has not, however, supported this in a rash or reflection-free manner. Having at its disposal writings inspired by God, theology analyzed them using the capabilities of the human mind and referring to the entirety of its oeuvre. However, while Revelation seemed to show God as the One who changes his decisions or is subject to feelings (which clearly implied an assumption about the changes taking place in Him), human thought as such persistently demanded someone perfect, totally different from what was created, and therefore unchangeable. As a consequence, the words from the Book of Malachi: "I, the LORD, do not change" (Malachi 3:6), ${ }^{\mathrm{T}}$ unsupported by relevant arguments turned out to be insufficient in themselves. The first centuries of Christianity faced allegations of polytheism and the mutability of God, which in the light of philosophical investigation seemed to be obvious to opponents. As a result, Christianity cleaned and adapted the achievements of history that could serve the issue of approximating the nature of God to people.

The article focuses on the immutability of God in Himself and the immutability of the Trinity in terms of Tertullian and Origen as the most creditable for this issue and the early representatives of the Western and Eastern ideas of the Church, and Thomas Aquinas, who as a representative of scholasticism, utilized the resources of ancient philosophy in his theological investigations.

\section{Early Christian Reflection on God's Immutability - Tertullian and Origen}

In undertaking a discussion with pagan culture, philosophy, and Judaism, Christianity defended the Gospel and defined its own conception of God and His relationship to the created order, showing Him

\footnotetext{
1 For biblical quotation we use English Standard Version (200I).
} 
as quite different, but also personal, loving, and acting in the world. ${ }^{2}$ Anti-trinitarian heresies, which appeared in the late second century were the stimulus that initiated the gradual development of Trinitarian dogma. ${ }^{3}$ The pre-Nicene Fathers, while not yet using the classic formulation of one God in three Persons, expressed the mystery of the Trinity in different terminology and always combined this terminalogy with the Trinity's interventions in the history of salvation. This line of thinking, perhaps too strongly emphasizing that the Son and the Holy Spirit are different from the Father though they nevertheless constitute unity with Him in His eternal being, caused anxiety in those anxious about monotheism. ${ }^{4}$

The necessity of defense against pagans and Jews who saw Christians as worshippers of two gods led, at the end of the Second Century, to the foundation of Monarchianism, the above mentioned Trinitarian heresy divided into adoptionist (dynamic) and modalistic (Unitarian, patripassianism) Monarchianism. ${ }^{5}$ Monarchianism (Greek $\mu$ ovń

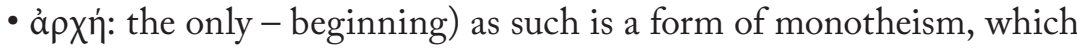
speaks of one beginning, one principle - God. Its adoptionist variation sees Jesus as only a man who was, however, elevated (adopted) by God to the dignity of God's Son during Baptism. Representatives of this way of thinking are: Paul of Samosata (condemned at the Synod of Antioch in 268) and Photinus of Sirmium (condemned at the Synod of Antioch in 35I). Modalistic monarchianism (Latin modus, mode, hence modalism) questions, on the other hand, the existence in God of "three eternally different Persons." The Father, the Son and the Holy Spirit are only three different modes of manifesting of one and internally undifferentiated God. Noet, Praxeas, and probably Sabellius are the earliest representatives of this trend and the negation of all diversity in

2 See T.G. Weinandy, Czy Bóg cierpi? (Does God Suffer?), przeł. J. Majewski, Poznań 2003, p. I48 with note 4. See also: G. Strzelczyk, Traktat o Jezusie Chrystusie, Warszawa 2005 pp. 296-297 and 315-316 (Dogmatyka, I).

3 B. Sesboüé, J. Wolinski, Historia dogmatów (Le Dieu du salut), vol. I, Bóg zbawienia, tłum. P. Rak, Kraków I999, p. I59; see also: J. D. Szczurek, Trójjedyny, Kraków 1999, p. I65.

4 B. Sesboüé, J. Wolinski, Historia dogmatów, vol. I, p. I59; J. N. D. Kelly, Poczq̨tki doktryny chrześcijańskiej (Early Christian Doctrines), przeł. J. Mrukówna, Warszawa I988, p. 90 .

Cf. B. Sesboüé, J. Wolinski, Historia dogmatów, vol. I, p. I6o; J. D. Szczurek, Trójjedyny, p. I74. 
God is visible in their approach, which finds confirmation in the words of Noet: "Christ Himself is the Father, and [...] it was the Father who was born, suffered and died," which expresses patripassianism. In this way "Unitarian" trends were softened with time.?

Faced with this deformed picture of Christianity the Church could not remain indifferent. Tertullian (c. 160-225) in the West, and Origen (c. $185-254)^{8}$ in the East, greatly helped the development of Trinitarian thought responding to individual accusations and overthrowing them.

Tertullian came from North Africa and was a lawyer and theologian whose thought was marked by stoicism ${ }^{9}$ and who in 207 joined the Montanists. He was also the first important Christian author who wrote in Latin and contributed greatly to Western thought by developing Trinitarian and Christological terminology.

Adversus Praxean is the work of Tertullian directed against Monarchianism, which is also "the first treatise of purely speculative Trinitarian theology." Responding to complaints, Tertullian refers mainly to the Scriptures of the Old and New Testaments, but confronting "evidence of faith with the requirements of reason" ${ }^{\text {Io }}$ is not alien to him. The accusations that Praxeas makes concerns the worshipping of two or three Gods and his views are summed up in the assertion that there is only one Lord, the Creator of the World, the Father, who is Jesus Christ Himself. ${ }^{\text {II }}$ Although Tertullian attached great importance to monotheism and referred to the loneliness of $\mathrm{God}^{, 2}$ he also argued that the

6 Hipolit, Contra Noetum, I. See also: P. Gavrilyuk, The Suffering of the Impassible God, Oxford 2006, p. 94 .

7 See B. Sesboüé, J. Wolinski, Historia dogmatów, vol. I, p. I6o-I6r; J. D. Szczurek, Trójjedyny, p. I74-I75;

See also: H. Pietras, Wprowadzenie, in: Trójca Święta, Tertulian, Przeciw Prakseaszowi, przeł. E. Buszewicz; Hipolit, Przeciw Noetosowi, przeł. S. Kalinkowski, wstęp i oprac. H. Pietras, Kraków 1997, pp. IO-I8.

8 Dates after:J. N. D. Kelly, Początki doktryny chrześcijańskiej, p. 9I and Io2.

$9 \quad$ J. N. D. Kelly, Poczatki doktryny chrześcijańskiej, p. 93, reminds us of this when he speaks of the "materialistic language" of Tertullian. See also: H. Pietras, Orygenes, Kraków 200I, pp. 34-35.

10 B. Sesboüé, J. Wolinski, Historia dogmatów, vol. I, pp. I67-I68; regarding identification of Praxseas see: H. Pietras, Wprowadzenie, in: Trójca Święta, p. I2.

11 See Tertullian, Adversus Praxean, III, I and I, I.

12 J. N. D. Kelly, Początki doktryny chrześcijańskiej, p. 9r; J. D. Szczurek, Trójjedyny, p. I77; In order to demonstrate the unity of God, Tertullian used the idea of monarchy, but understood differently even by Christians themselves. In Adversus 
existence of the Son of God did not contradict unity. ${ }^{13}$ The Son of God comes from the substance of the Father just as the Holy Spirit does and together they "constitute oneness and not the one, as is said: I and the Father are one, regarding the unity of substance, not singularity of number." ${ }^{14}$ Their unity cannot be reduced to a mathematical calculus, as in the neuter case (Latin unum) used in the words of Jesus means "unity, likeness, communication" and so the identity of the substance, rather than the singular (this could be rendered by unus, one). ${ }^{\text {I5 }}$ The Word, like Wisdom and Reason, has always existed in God, becoming the Son at the time when it was pronounced, by God the Creator in the process of creation. ${ }^{16}$ Tertullian is also the first among the Latinists who, speaking of the Father, the Son, and the Spirit as Persons, uses the word trinitas, stating that God is a Trinity. ${ }^{17}$

Thomas Weinandy notes that Tertullian's position on feelings, and thus the suffering and impassibility of God and the associated potential changes, is marked by a certain tension. To understand it one should look at it through the prism of the goodness of God, His eternal and basic attribute, which $\mathrm{He}$ uses in a rational manner that implies that $\mathrm{He}$ is perfect. According to Tertullian the goodness of God demands judging evil and therefore displaying feelings (including negative ones such as anger) without which He could not be good, since "kindness is the 'mother' of all feelings." Without kindness He would not be a true God. Thus, on the one hand, He is good in Himself, and on the other, His goodness "is expressed appropriately to changes in the created order." As One who is eternally and perfectly good, He does not change His emotional states and remains unchangeable. On the other hand, the way of expressing His goodness, as well as how man experiences it,

Praxean, III, 2 he states how he understands this term. See. H. Pietras, Wprowadzenie, in: Trójca Śrwięta, p. Io.

13 G. Strzelczyk, Traktat o Jezusie Chrystusie, p. 3I3.

14 Tertulian, Adversus Praxean, XXV, I.

15 Tertulian, Adversus Praxean, XXII, Io-II; J. N. D. Kelly, Początki doktryny chrześcijańskiej, p. 93; H. Pietras, Wprowadzenie, in: Trójca Śrwięta, pp. I8-19; see also: G. Strzelczyk, Traktat o Jezusie Chrystusie, p. 3I4.

16 Tertulian, Adversus Praxean, V-VII; J. N. D. Kelly, Początki doktryny chrześcijańskiej, p. 9r; see also: B. Sesboüé, J. Wolinski, Historia dogmatów, vol. I, pp. I73-I75; J. D. Szczurek, Trójjedyny, p. I77.

17 Cf. Tertulian, Adversus Praxean, III, XI, XII; J. N. D. Kelly, Poczatki doktryny chrześcijańskiej, p. 92. 
is variable, such as anger against the sinner, or mercy towards the repentant. One cannot, as Marcion ${ }^{\mathrm{I} 8}$ Tertullian's adversary on the subject, view God through the prism of man, assign Him the same nature, and conclude that $\mathrm{He}$ is mortal just because it is said that He can express negative feelings. "God has feelings in a divine way," and not in a human and changeable way. ${ }^{\text {I9 }}$

In terms of Tertullian, God is immutable also because $\mathrm{He}$ is beyond time. That which exists in time is subject to change. But God is eternal and the essence of eternity is not to be subject to loss. ${ }^{\circ}$ Eternity, as Tertullian says, "is not capable of change, since, being an eternity, it cannot in any way be subject to change." ${ }^{21}$ It does not have time, being itself "all time" and "whatever happens [in it], does not change." ${ }^{22}$ So God in His eternity cannot become more or less perfect, and if He works, He is not subject to the same effect. As eternally perfect and good He exists without beginning and without end, in eternity that is not subject to change. ${ }^{23}$

By analyzing the thought of Tertullian, Thomas Weinandy notes that, despite certain ambiguities and misunderstandings in his thoughts, Tertullian advocates maintaining two biblical truths - one about the total otherness of God and the other about His kindness toward creatures. Seeing Him as wise, good, and eternal, he concludes that as such $\mathrm{He}$ is ontically immutable and impassible (does not experience changes of emotional states). ${ }^{24}$

Joseph Hallman ${ }^{25}$ has a slightly different perspective on the views of Tertullian than Thomas Weinandy. He argues that Tertullian's position

18 Tertulian, Adversus Marcionem, II, I6.

19 Cf. T. G. Weinandy, Czy Bóg cierpi?, pp. 175-180; see also: J. Hallman, The Descent of God, Minneapolis I99I, pp. 5I-52.

20 Cf. T. G. Weinandy, Czy Bóg cierpi?, p. I8o; J. Hallman, The Descent of God, p. 6r; On the subject of eternity see: K. Rahner, H. Vorgrimler, Maty stownik teologiczny (Kleines Theologisches Worterbuch), przeł. T. Mieszkowski, P. Pachciarek, Warszawa 1987, ref. 'wieczność', pp. 54I-542; J. D. Szczurek, Trójjedyny, pp. 25I-254.

21 Tertulian, Adversus Hermogenem, I2; quoted after: T. G. Weinandy, Czy Bóg cierpi?, p. I80.

22 Tertulian, Adversus Marcionem, I, 8.

23 Cf. T. G. Weinandy, Czy Bóg cierpi?, p. I8o; see also: J. Hallman, The Descent of God, pp. 59-6r.

${ }^{24} C f$. T. G. Weinandy, Czy Bóg cierpi?, pp. I80-18I.

25 T. G. Weinandy, Czy Bóg cierpi?, note Io4, pp. I8I-I84 analyzes J. Hallman's interpretation of Tertulian's thoughts showing what is missing in it and the erroneous conclusions. 
is inconsistent both in terms of God and the Incarnation because he adopted the assumptions of Greek philosophy. These assumptions made it impossible for him to keep an entirely biblical perspective. ${ }^{26}$

According to Joseph Hallman, Tertullian defends the idea of a changing and passible God in De carne Christi, thus explaining the possibility of the Incarnation, but later contradicts himself in Adversus Praxean (XXVII, I3). ${ }^{27}$ Considering the question of how the Word became flesh Tertullian also asks whether "[It] turned into the body (transfiguratio) or put it on." In response, he states: "Certainly It put it on. Besides, we must believe that God, as eternal, is immutable and does not transform. Transformation is, after all, the destruction of the previous state." But as noted by Thomas Weinandy, transformation understood in such a way refers only to what was created while in the context of the Incarnation it denotes a new way of existence for God who always remains the same. ${ }^{28}$ By becoming man, the Son of God does not "change" Himself and so does not cease to be God. He remains true God and true man: "No doubt both individual substances retain their individual distinctiveness [...]. Here we see the two states not mixed, but united in one person of God and man: Jesus." ${ }^{29}$ The unchanging God can become a man without changing. ${ }^{30}$

In the East in Alexandria, Origen like Tertullian was influenced by the intellectual currents of his era and benefited from the philosophical achievements of history hence his reflection on the mystery of the Trinity is marked by Middle Platonism. He was also familiar with the first heresies - Monarchianism and Adoptionism..$^{3 \mathrm{~T}}$ Moreover, in addition to Plotinus, he is regarded as "the most versatile mind of his time."

26 Cf. J. Hallman, The Descent of God, p. 62 and p. 66.

27 C.f. J. Hallman, The Descent of God, p. 63 with note 38 and pp. $65-66$, where the author says that Tertulian was not able to reconcile changeability of the Son in Incarnation with immutability of God; T. G. Weinandy, Czy Bóg cierpi?, note I04, p. I83.

28 Tertulian, Adversus Praxean, XXVII, 6-7; T. G. Weinandy, Czy Bóg cierpi?, note I04, p. I83.

${ }_{29}$ Cf. Tertulian, Adversus Praxean, XXVII, pp. 7-13; B. Sesboüé, J. Wolinski, Historia dogmatów, vol. I, p. I80.

30 Cf. T. G. Weinandy, Czy Bóg cierpi?, note 104, pp. 182-183.

31 Cf. J. N. D. Kelly, Początki doktryny chrześcijańskiej, p. Ioz; J. D. Szczurek, Trójjedyny, p. I78; B. Sesboüé, J. Wolinski, Historia dogmatów, vol. I, p. I92; T. G. Weinandy, Czy Bóg cierpi?, p. I7o; H. Pietras, Wprowadzenie, in: Orygenes, O zasadach, przekł. i oprac. S. Kalinkowski, Kraków I996, p. Io and pp. 3I-32; H. Pietras, Origenes, pp. 35-36. 
Although, according to general opinion, the Second Council of Constantinople (553) condemned Origen ${ }^{32}$ and because of this he is inscribed in our consciousness as a heretic. A number of authors (e.g. Hans Urs von Balthasar, Henri de Lubac) currently highlight the orthodoxy of his faith (the exception is the theory of the preexistence of souls), and the Second Vatican Council (1962-I965) quotes him eight times. ${ }^{33}$

The categories of Middle Platonism were used by Origen in his reflection on the Holy Trinity, so God the Father was seen by him as the Monad, the One, Reason, and the Source, "from which all spiritual beings, and all understanding originate." ${ }^{34}$ Only he was God in the strict sense, only he was not begotten and, what he strongly emphasized, was immaterial, ${ }^{35}$ The Son was His faithful semblance and mediator, His own eternal act of the Father who is outside time and unchanging. ${ }^{36}$ Although His divinity was derived and He was called 'the second' God, it cannot be disputed that as such He was indeed God. ${ }^{37}$ The Holy Spirit is, in turn, "the highest of beings that the Father created through Christ." ${ }^{8}$

Characteristic in the thought of Origen was the perception of the Father, the Son, and the Spirit as eternally existing, separately as "three

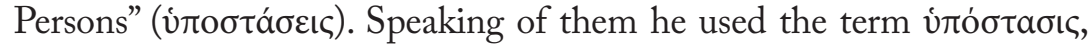
derived from Stoicism, which was then used interchangeably with oủoía,

32 F. Diekamp, Die origenistischen Streitigkeiten im sechsten Jahrbundert und das fünfte allgemeine Concil, Münster I899, pp. 66-I38. He showed, however, that Origen was condemned at the request of Justinian even before the formal opening of the debates of the council, hence the condemnation is not included in the set of his files, Cf. Constantinople II (553) in DSp I, 294-295 anathematism II; Constantinople III (680-68I) in DSp I, 310-3II; and Nicaea II (787) in DSp I, 334-335.

33 Cf. B. Sesboüé, J. Wolinski, Historia dogmatórw, vol. I, p. I84; J. N. D. Kelly, Początki doktryny chrześcijańskiej, p. Io2; H. Pietras, Wprowadzenie, in: Orygenes, $O$ zasadach, p. 7; see also: S. Kalinkowski, Wstęp, in: Pamfil z Cezarei, Obrona Origenesa, Rufin z Akwilei, O sfatszowaniu pism Origenesa, tłum., wstęp i oprac. S. Kalinkowski, Kraków 1996, pp. 5-8 (Źródła Myśli Teologicznej, 3)

34 Origen, De principiis, I, I, 6.

35 J. N. D. Kelly, Początki doktryny chrześijansskiej, p. Io3; J. D. Szczurek, Trójjedyny, p. I78; B. Sesboüé,J. Wolinski, Historia dogmatów, vol. I, p. I88; Origen, De principiis, I, I, I-4; Origen, Contra Celsum, VI, 64.

${ }^{36}$ Cf. J. N. D. Kelly, Początki doktryny chrześcijańskiej, p. Io3; Origen, De principiis, I, 2, 4 .

37 Origen, Contra Celsum, V, 39 and VII, 57; see also: J. N. D. Kelly, Poczatki doktryny chrześcijańskiej, p. Io3 and p. Io5; B. Sesboüé, J. Wolinski, Historia dogmatów, vol. I, p. I88.

38 J. D. Szczurek, Tróijedyny, p. 178-I79. 
the Platonic term. Both meant actual existence (as opposed to what exists merely in the mind), what a thing is, but Origen began to use the first one to point to an individual being, an individual existence. Therefore, he saw an error of modalism in distinguishing the Father, the Son, and the Spirit only in thought (conceptually) and not in terms of numbers. For Origen Three Divine Persons, though in fact separate, were united. ${ }^{39}$

In Contra Celsum Origen states that God is not part of being, on the contrary, that "being is involved in God." So one cannot put him on par with what is created. God is different and the difference is based on the act of creation. Moreover, by nature, as being immaterial and pure substance, $\mathrm{He}$ is "stable and unchanging" hence "movement is not [His] feature." ${ }^{\circ}$ The argument put forth by Origen for permanence and immutability was mainly against the Stoics, for whom everything that existed had to be material and therefore subject to change and destruction, including God. ${ }^{4 r}$

Like Tertullian, Origen appears to be inconsistent. On the one hand he defends God's immutability and impassibility, acknowledging that God's nature is not subject to change and all passions are alien to it. ${ }^{42} \mathrm{On}$ the other hand, however, he talks about His feelings - compassion, pity, and pain, which caused the Son of God to become man, and the emotions and suffering that accompany the Father Himself when He pities people and "puts Himself in a situation where he could not find Himself because of the greatness of His nature." ${ }^{43}$ So not only the Son suffers and not only in his humanity, since suffering includes, as a motive of the Incarnation, also His "divine status." ${ }^{44}$ Origen's intuition coincides with the intuition of Tertullian here - we should take two seemingly contradictory truths: of the impassibility and passibility of God. Scripture,

39 Cf. J. N. D. Kelly, Początki doktryny chrześcijańskiej, pp. Io3-Io4; B. Sesboüé, J. Wolinski, Historia dogmatów, vol. I, p. I99.

40 Origen, Contra Celsum, VI, 64; T. G. Weinandy, Czy Bóg cierpi?, p. ı7ı; H. Pietras, Orygenes, p. 35 .

41 T. G. Weinandy, Czy Bóg cierpi?, p. I72; Origen, Contra Celsum, I, 21.

42 Cf. T. G. Weinandy, Czy Bóg cierpi?, p. I7I and p. I73.

43 Origen, In Ezechielem homiliae, VI, 6; T. G. Weinandy, Czy Bóg cierpi?, p. I72; see also: W. Hryniewicz, Pascha Chrystusa w dziejach cztowieka $i$ wszechsiwiata. Zarys chrześcijańskiej teologii paschalnej, vol. 3, Lublin I99I, p. 269 with note III, where the author quotes a fragment from In Ezechielem homiliae, VI, 6 and states that it would be a mistake to "consider Origen an advocate of the so called patripassianism."

44 T. G. Weinandy, Czy Bóg cierpi?, p. I73. 
when speaking of any (positive and negative) feelings in God, must be interpreted metaphorically because one cannot look at God as a man and assign him "human affection." 45 The feelings, of which the Bible speaks, do not mean "changes in emotional state," but "predicate aspects of God's immutable passionate love for humankind." 46

Origen was the first to philosophically and biblically justify that the Son was not created at the beginning of time but is begotten and eternal. ${ }^{47} \mathrm{His}$ reasoning was based on the assumption that God is immutable because He exists in eternity. This eternity, however, is not related to the passing of time. Begetting or creating the Son therefore could not occur at some particular moment because that would be associated with time. Thus, God the Father would not have always been the Father, and would have to only become Him, and this would entail a change that in relation to God is not acceptable. The Son, in turn, could not be called the perfect image of the Father, because he would not be eternal just like He is. Furthermore, assuming the begetting of the Son at a given moment in time, one could ask why it did not happen at an earlier or later time. ${ }^{48}$ Putting an end to discussions of this type, Origen says: "The Father is the source and origin of the Son and the Holy Spirit and in the whole Trinity we shouldn't anticipate anything earlier or later." ${ }_{4}$ The Father begets the Son eternally and it is a continuous relationship of origin, lasting even after the Incarnation..$^{\circ}$ It should also be noted that Origen does not speak yet about consubstantiality of the Father and the Son. For he always presents their unity as a "unity in love, will and action." ${ }^{\mathrm{r}}$

Origen was one of the first to analyze the issue of the mutual relationship of the Logos and the humanity of Jesus in the Incarnation. Here was based the soteriological premise - human salvation is possible only when the Logos is truly united with humanity (through the

45 Origen, Contra Celsum, IV, 72.

46 Cf. T. G. Weinandy, Czy Bóg cierpi?, p. I75.

47 H. Pietras, Wprowadzenie, in: Orygenes, O zasadach, p. 33; H. Pietras, Orygenes, p. 33; J. N. D. Kelly, Początki doktryny chrześcijańskiej, p. Io4; B. Sesboüé, J. Wolinski, Historia dogmatów, vol. I, p. I89.

48 Cf. H. Pietras, Orygenes, pp. 36-38; see: Origen, De principiis, I, 2, 2 and IV, 4, I, where Origen says that the birth of the Son does not mean the expanding of God, as is the case with man. Origen, De principiis, II, 2, I.
49 Origen, De principiis, II, 2, I.
50 H. Pietras, Orygenes, p. 38.
51 Cf. J. N. D. Kelly, Poczatki doktryny chrześcijańskiej, pp. I04-105. 
soul)..$^{52}$ This must be the unification of the ontological character, but Origen does not explain of what it would consist. There is no doubt, however, that Jesus Christ has in mind two kinds of unmixed and unaltered natures ${ }^{53}$ - divine and human, which are united in Him as a single entity so that it is possible to apply to him the words such as "the Son of God died." ${ }^{4}$ Explaining to Celsus that God is "indestructible, noncomposite, simple and indivisible," and supporting his conviction of His immutability with the words of Scripture: "I, the LORD do not change" (Malachi 3:6), Origen refutes the allegations that the Incarnated God had to change (e.g. from good to evil). He - "immutable by nature - descends among people through His providence and care for human affairs," ${ }_{55}$ and the mere fact of His becoming fully human while remaining fully divine, is a mystery impossible to explain "even for all heavenly powers. ${ }^{56}$

\section{Immutability of God and the Trinity in Terms of Thomas Aquinas}

The development of philosophical culture in medieval Europe was made possible as a result of the renewed interest in non-Christian philosophy - Arab, Jewish, and Greek (mainly Aristitelianism). ${ }^{57}$ This was followed by the establishment of new universities and religious orders, such as, the Dominicans and Franciscans, from which emerged such thinkers as Thomas Aquinas, Bonaventure, and John Duns Scot. The twelfth and thirteenth centuries also led to rational cognitive tendencies, which have their resonance in later centuries..$^{8}$

52 G. Strzelczyk, Traktat o Jezusie Chrystusie, p. 318; see: Origen, De principiis, II, 6, 3.

53 Nature for Origen is what determines the identity of being, thus deciding on the scope of its activities. It is already an ontological category. G. Strzelczyk, Traktat o Jezusie Chrystusie, pp. 318-320; see: Origen, De principiis, I, 2, I and II, 6, 2; Origen, Contra Celsum, III, 28.

54 Cf. G. Strzelczyk, Traktat o Jezusie Chrystusie, pp. 317-321; B. Sesboüé, J. Wolinski, Historia dogmatów, vol. I, pp. 20I-202.

55 Origen, Contra Celsum, IV, I4 and I, 2I.

56 Origen, De principiis, II, 6, 2.

57 Cf. M. Gogacz, Elementarz metafizyki, Warszawa 1987, p. I41; M. Krąpiec, T. Żeleźnik, Arystotelesa koncepcja substancji: ogólna teoria I wybór tekstów, Lublin I966, p. 58, I87.

58 M. Krąpiec, T. Żeleźnik, Arystotelesa koncepcja substancji, p. 59. 
Albert the Great and Thomas Aquinas (I225-I274) brought a kind of revolution to philosophical thought..$^{59}$ Taking into account the thought of Aristotle, ${ }^{60}$ applying it to Christianity, and brokering a new concept of being and man, they exerted a tremendous influence on its very core. It was not an easy task because, in accordance with common belief, one should submit to the opinion that "to know the truth is the work of the joint research in different times and different places." Therefore Thomas Aquinas, despite the "novelty" of his teaching, original ideas, and formulations, still referred to the recognized and "existing" authorities such as Aristotle, Boethius, and St. Augustine, interpreting their views through the prism of his own observations and thus confirming his concepts using their thought. ${ }^{6 r}$

Thomas Aquinas' accomplishment is undoubtedly introducing a new understanding of being - being as existing. Thus so far unnoticed, existence became "a factor in the actualization of a particular being, that a being is truly real." ${ }^{62}$ Just as the biblical and patristic tradition concluded that God is omnipotent, all-perfect, eternal, immutable, and impassible, and His very nature also requires these attributes, for Thomas Aquinas "the nature of God is existing, that He is ipsum esse ('existence itself'), and thus actus purus ('pure act')." ${ }^{3} 3$ Essence and existence, the same in God, are thus the basis of His immutability. ${ }^{64}$

59 A short biography of Thomas Aquinas and a discussion of various insights into his thought in: M. Gogacz, Elementarz metafizyki, pp. I44-I5I.

60 Cf. A. Baron, Neoplatonska idea Boga, Kraków 2005, p. 47.

61 Cf. M. Krąpiec, T. Żeleźnik, Arystotelesa koncepcja substancji, pp. 62-63.

62 M. Krąpiec, T. Żeleźnik, Arystotelesa koncepcja substancji, pp. 64-65.

63 T. G. Weinandy, Czy Bóg cierpi?, p. 209; Thomas Aquinas, S. th., I, 3, 4 and on the difference between existing of (immutable) God and (mutable) creatures I, 9, 2; J. D. Szczurek, Trójjedyny, pp. 228-230 says that Thomas Aquinas understands God as self-contained existence (ipsum esse subsistens), in which every other existence participates. He also points out that in the Polish language the term "existence" (esse) is richer than "being" and renders Aquinas' definition in a better way as the definition relates to the "act of true, fulfilled continuance beyond nothingness, i.e., the content of the infinitive "to exist." Cf. T. G. Weinandy, Czy Bóg cierpi?, pp. 210-2I2. Pure act in neoplatonic thinking - see A. Baron, Neoplatońska idea Boga, pp. 259-317. See also: W. Breuning, Nauka o Bogu, przekł. J. Fenrychowa Kraków 1999, pp. 92-94 (Podręcznik Teologii Dogmatycznej, traktat II); E. Gilson, Bóg i filozofia, przeł. M. Kochanowska, Warszawa I96I, p. 62 and 67; L. Łysień, Bóg, rozum, wiara: problematyka filozofii Boga od Talesa z Miletu do G. W. F. Hegla, Kraków 2003, pp. 63-64, 68.

64 Z. Nerczuk, Komentarz do Kwestii ro. O wieczności Boga, in: Tomasz z Akwinu, Summa teologii. Traktat o Bogu (entries I-26). 
God, as "the first being" (primum ens), ${ }^{65}$ pure existence, and pure act, is the most real and perfect, because nothing is missing in the way of His excellence, He does not realize any potency. ${ }^{66}$ Thus, as an allperfect and free from movement, He is immutable. This immutability, as Thomas Weinandy points out, however, is not static or indifferent, but active and dynamic, resulting from the fact that as a pure act "He cannot become ontically more in the act." His immutability cannot be then compared with the immutability of a rock, because a rock is simply static and inert, and $\mathrm{He}$ is so dynamic [...] that no change could make Him more active." "Go "God then is supremely immutable because He is supremely in act." ${ }^{8}$ This distinguishes him from the "prime matter" which, also being immutable, is immutable on the basis of being totally in potency, thus having "the highest degree of passivity and willingness to accept." ${ }^{69}$ It should be emphasized also that immutability in reference to God in Thomas Aquinas refers to the ontological level and is absolute immutability, which excludes any changes. This is "metaphysical immutability because God can neither begin nor cease to exist; physical immutability, as He cannot change internally or yield to an action of an external cause; intentional immutability, because He cannot expand or limit His knowledge, and finally moral immutability, because He cannot change His free choices." 70

The issue of immutability is also tied to the topic of emotions in God. Thomas Aquinas denies their existence, although he does so by negating the existence of a changing emotional process in God, which is characteristic of humans. ${ }^{71}$ As a result, feelings (e.g. joy, love) exist in

65 Cf. Thomas Aquinas, S. th., I, 2, 3; Z. Nerczuk, Komentarz do Kwestii ro. O wieczności Boga, p. 540.

66 Thomas Aquinas, S. th., I, 9, I.

67 T. G. Weinandy, Does God change? The Word's Becoming in the Incarnation, Petersham 1985, pp. 78-79; quoted after: T. G. Weinandy, Czy Bóg cierpi?, pp. 215-216; D. Oko, Doskonale obojętny? Zarys wspótczesnej krytyki Tomaszorvego pojmowania niezmienności Boga,"Analecta Cracoviensia" 27 (2005), p. 62.

68 Cf. T. G. Weinandy, Czy Bóg cierpi?, pp. 213-215.

69 Cf. Z. Nerczuk, Komentarz do Kwestii Io. O wieczności Boga, p. 542.

70 D. Oko, Doskonale obojętny?, p. 62; S. Ziemiański, Teologia naturalna. Filozoficzna problematyka Boga, Kraków 1995, pp. 306-307; see also: I. Różycki, Dogmatyka katolicka, vol. I, pp. I7I-I72.

71 T. G. Weinandy, Czzy Bóg cierpi?, pp. 292-294 also opposes addressing some concepts to God (such as "suffering"), which might suggest that He is subject to some emotional changes. 
God, but speaking of them one should pay attention to the fact that God has them within His unchanging nature (and not within an emotional process), as such they do not bring His perfection into question. Thus, since God is pure act, His feelings are completely in the act. For example, to say that God is love means that he is "pure love in act, and thus absolute passion in act." 72

Since these philosophical considerations are based on human reason rather than on revelation, they concern God as one (reason alone has not yet reached this, that God is a Trinity of Persons) and the question of God's immutability if framed within His nature and attributes. For a full picture of the immutability of God one should look deeper into the nature of the Trinity.73

The Father, the Son, and the Holy Spirit exist "by themselves as different subjects" and are referred to as "different persons solely within references to themselves." Their mutual relationship then is what differentiates them. ${ }^{74}$ The Father, the Son, and the Holy Spirit exist "by themselves as different subjects" and are referred to as "different persons solely within reference to themselves." Their mutual relationship then is what differentiates them. ${ }^{75}$ Being self-contained, only in mutual relationship, the Divine Persons are relations in act, and as relation, selfcontained in act, the Father, Son, and Holy Spirit are unchanging. ${ }^{.6}$ And again, immutability is not a result of their static character or inertia, but a consequence of the lack of relational potency, whose realization would be necessary for the persons of the Trinity to become more relational. Being completely self-contained relations in act, completely dynamic and active, They cannot become even more dynamic and active.77

These considerations lead to the conclusion that Thomas Aquinas anchored immutability of God on three assumptions. The first one I, 20, I.

72 Cf. T. G. Weinandy, Czy Bóg cierpi?, pp. 219-220; Thomas Aquinas, S. th.,

73 T. G. Weinandy, Czy Bóg cierpi?, p. 200 and 209.

74 T. G. Weinandy, Czy Bóg cierpi?, p. 201 with note 3; Thomas Aquinas, S. th., I, 29, 4 and I, 28, I. See also: C. J. Hefele, H. Leclercq, Histoire des Conciles d'après les documents originaux, tome 3, première partie, Paris I909, p. 3II nn.), Cf. J. D. Szczurek, Trójjedyny, pp. 203-208; see also: C. Bartnik, Dogmatyka katolicka, pp. 219-222; F. Courth, Bóg trójjedynej mitości, pp. 225-229.

75 T. G. Weinandy, Czy Bóg cierpi?, p. 203.

76 T. G. Weinandy, Czy Bóg cierpi?, pp. 206-207.

77 T. G. Weinandy, Czy Bóg cierpi?, pp. 207-208. 
indicates God's possession of present existence in the highest degree, and the simultaneous lack of potency. Transition from potency to act is therefore not possible, thus providing a guarantee of immutability. Then, since the transition from potency to act is a change, and takes place only in complex beings, it does not apply to God, because $\mathrm{He}$ is simple being..$^{78}$ Finally, God, as an ontically perfect Being, does not change, because $\mathrm{He}$ has all the positive properties. Any change would suggest His imperfection and the need to "purchase" what He lacks, that is, the transition from potency to act. ${ }^{9}$

Aquinas' view of the immutability of God cannot be seen only through the prism of the Aristotelian Unmoved Mover, although he used Aristotelian philosophy (he adopted Aristotles definition of motion, time, and space) and is usually associated with it. Please note however, that the philosophy of Stagirite was reinterpreted by him in the light of Christian Revelation, thereby transforming the idea of selfthinking Thought in "the One who is." ${ }^{\circ}$

What undoubtedly connects Aristotle and St. Thomas Aquinas on the issue of the immutability of God is that they consider Him to be fully realized, and thus immutable and therefore eternal..$^{8 \mathrm{I}}$ Jacek Salij lists four elements, however, which differentiates both philosophers on the issue of the immutability of God. First of all, Aristotle did not know the truth about creation ${ }^{8_{2}}$ hence the Unmoved Mover serves him

78 Thomas Aquinas, S. th., I, 3, 7 argues that God is a simple being, among others because $\mathrm{He}$ is not the body, He does not consist of matter and form, subject and accidents, nature and difference, and the essence and existence and the nature and the subject are one in Him. $\mathrm{He}$ is also the first being, the first efficient cause and the existence, which also speaks for His simplicity. See Z. Nerczuk, Komentarz do Kwestii Io. O wieczności Boga, p. 543. Simple being in neoplatonic thinking - see A. Baron, Neoplatońska idea Boga, pp. 137-139.

79 Cf. J. Życiński, Bóg Abrahama i Whiteheada, pp. 205-207; D. Oko, Doskonale obojętny?, p. 6r.

80 Cf. E. Gilson, Bóg i filozofia, p. 6r; Z. Nerczuk, Komentarz do Kwestii ro. O wieczności Boga, p. 538 .

81 Cf. Z. Nerczuk, Komentarz do Kwestii ro. O wieczności Boga, p. 538.

82 Thomas Aquinas, referring to the creation of the world, introduces a Christian theme to the Aristotelian argumentation. Considering the issue of change caused by an external factor, he comes to the conclusion that creation by definition is mutable, as it was called into existence by an eternal being (God) and is dependent on Him in its existence (if God did not keep the world in existence, it would cease to exist). Z. Nerczuk, Komentarz do Kwestii ıo. O wieczności Boga, p. 546. 
to explain the eternal motion of celestial bodies. Secondly, he did not know that He works on a voluntary basis and gives existence to what exists. Thirdly, the Unmoved Mover in Aristotle's system is a supreme being, the most important (because it protects against degradation into chaos) and transcendent, but also one of the many elements of the "wholeness of being." So the philosopher knows nothing "about His real ubiquity." Fourth, although he is pure act, "he is wholly immersed in himself and beyond propelling the universe in movement, he is not involved in anything which is external to him." ${ }^{3}$

God is pure act and works as such. Only He has the ability to invoke things into existence. ${ }^{84}$ Being actus purus, $\mathrm{He}$ is unchangeable, which does not prevent action. On the contrary, His constant - because fully realized - power, allows Him to create and it is precisely the necessary condition. God's action does not include any transition from potency to act, hence it is pure act, and as such also applies to the act of creation. ${ }^{85}$ Recognizing God as mutable destroys His ontological distinction, bringing Him to "the most perfect being among many beings," while between Him and what was created there is a great difference. ${ }^{86}$ The "supernatural" action of God in the created order should not be understood as God's entry in this order in such a way that he becomes just another element acting in it. He would then, of necessity, be subject to change. His "supernatural" activity means that He "remains ontologically distinct from the created order as the Wholly Other, bringing about a change in the created order by relating a thing or person to himself as the Wholly Other in a new manner." ${ }^{87}$

83 Cf. J. Salij, Jak nieskończenie doskonaty i niezmienny Bóg może interesowaí się swoim stworzeniem?, p. 6.

84 Only God exists by Himself, which is the condition of creation. If other entities have been gifted by Him with such a possibility, they would have the same power as He to exist as pure act. It is impossible, because they would then be an eternal God. T. G. Weinandy, Czy Bóg cierpi?, note 63, p. 232.

85 T. G. Weinandy, Czy Bóg cierpi?, p. 229, pp. 232-233 and note 64 and note 69, pp. $238-239$.

86 T. G. Weinandy, Czy Bóg cierpi?, p. 239 and note 7o; J. D. Szczurek, Trójjedyny, p. 342 .

87 Cf. T. G. Weinandy, Czy Bóg cierpi?, note 6I, pp. 230-23I. 


\section{BiBLIOGRAPHY}

Baron A., Neoplatońska idea Boga, Kraków 2005.

Breuning W., Nauka o Bogu, przekł. J. Fenrychowa, Kraków 1999 (Podręcznik Teologii Dogmatycznej, traktat II).

Diekamp F., Die origenistischen Streitigkeiten im sechsten Jahrhundert und das fünfte allgemeine Concil, Münster I899.

Gavrilyuk P., The Suffering of the Impassible God, Oxford 2006.

Gilson E., Bóg i flozofia, przeł. M. Kochanowska, Warszawa I96r.

Gogacz M., Elementarz metafizyki, Warszawa I987.

Hallman J. M., The Descent of God, Minneapolis I991.

Hefele C. J., Leclercq H., Histoire des Conciles d'après les documents originaux, tome 3, première partie, Paris I909.

Hippolytus, Contra Noetum.

Hipolit, Przeciw Noetosowi, przeł. S. Kalinkowski, wstęp i oprac. H. Pietras, Kraków 1997 .

Hryniewicz W., Pascha Chrystusa w dziejach cztowieka i wszechświata. Zarys chrześcijańskiej teologii paschalnej, vol. 3, Lublin r991.

Kalinkowski S., Wstę, in: Pamfil z Cezarei, Obrona Orygenesa, Rufin z Akwilei, O sfatszowaniu pism Orygenesa, tłum., wstęp i oprac. S. Kalinkowski, Kraków 1996, pp. 5-8 ('́ródła Myśli Teologicznej 3).

Kelly J. N. D., Poczq̨tki doktryny chrześcijańskiej (Early Christian Doctrines), przeł. J. Mrukówna, Warszawa I988.

Krąpiec M., Żeleźnik T., Arystotelesa koncepcja substancji: ogólna teoria i wybór tekstów, Lublin 1966.

Eysień L., Bóg, rozum, wiara: problematyka filozofii Boga od Talesa z Miletu do G. W. F. Hegla, Kraków 2003.

Nerczuk Z., Komentarz do Kwestii ro. O wieczności Boga, in: Tomasz z Akwinu, Summa teologii. Traktat o Bogu (poz. I-26).

Oko D., Doskonale obojętny? Zarys wspótczesnej krytyki Tomaszowego pojmowania niezmienności Boga,"Analecta Cracoviensia” 27 (2005).

Origen, Contra Celsum.

Origen, De principiis.

Origen, In Ezechielem homiliae.

Pietras H., Orygenes, Kraków 2001.

Pietras H., Wprowadzenie, in: Orygenes, O zasadach, przekł. i oprac. S. Kalinkowski, Kraków 1996. 
Pietras H., Wprowadzenie, in: Trójca Święta, Tertulian, Przeciw Prakseaszowi, przeł. E. Buszewicz; Hipolit, Przeciw Noetosowi, przeł. S. Kalinkowski, wstęp i oprac. H. Pietras, Kraków 1997, pp. Io-I8.

Rahner K., Vorgrimler H., Maty stownik teologiczny (Kleines Theologisches Worterbuch), przeł. T. Mieszkowski, P. Pachciarek, Warszawa 1987.

Salij J., Jak nieskończenie doskonaty i niezmienny Bóg może interesować się swoim stworzeniem?, „Przegląd Tomistyczny” ${ }_{3}$ (2007) nr I, p. I6I-I72.

Sesboüé B., Wolinski J., Historia dogmatów (Le Dieu du salut), vol. I, Bóg zbawienia, tłum. P. Rak, Kraków 1999.

Strzelczyk G., Traktat o Jezusie Chrystusie, Warszawa 2005 (Dogmatyka, I).

Szczurek J. D., Trójjedyny, Kraków 1999.

Tertulian, Adversus Hermogenem.

Tertulian, Adversus Marcionem.

Tertullian, Adversus Praxean.

Weinandy T. G., Czy Bóg cierpi? (Does God Suffer?), przeł. J. Majewski, Poznań 2003.

Weinandy T. G., Does God change? The Word's Becoming in the Incarnation, Petersham 1985.

Ziemiański S., Teologia naturalna. Filozoficzna problematyka Boga, Kraków 1995. 